\title{
PENGEMBANGAN DESA WISATA KEPUNG BUDAYA DESA WATULIMO, KECAMATAN WATULIMO, KABUPATEN TRENGGALEK
}

\author{
Vega Aditama ${ }^{1}$, Budi Fathony ${ }^{2}$, Lalu Mulyadi ${ }^{3}$ \\ ${ }^{1}$ Program Studi TeknikSipil , InstitutTeknologiNasional Malang, Indonesia-65140 \\ ${ }^{2,3}$ Program Studi Arsitektur , InstitutTeknologiNasional Malang, Indonesia-65140
}

\begin{abstract}
ABSTRAK
Pengembangan pariwisata Kabupaten Trenggalek diarahkan pada pengembangan wisata alam dan budaya, pemasaran daya tarik wisata, pembinaan dan pengembangan nilai-nilai budaya, pembinaan kesenian, peninggalan sejarah yang bertujuan untuk mengembangkan daya tarik wisata potensial sebagai daya tarik utama bagi wisatawan, yang menjadikan pariwisata sebagai sarana peningkatan pendapatan masyarakat, dan daerah, serta media bagi penciptaan lapangan dan kesempatan kerja. Di Desa Watulimo, Kecamatan Watulimo dilakukan serangkaian kegiatan yang dimulai dengan Survei Pendahuluan, Pengumpulan Data Lapangan, Analisa Data dan pembuatan perencanaan wisata. Dengan demikian tersusunlah Masterplan Desa Wisata Kepung Budaya dengan memperhatikan bangunan tata ruang dalam, keseimbangan, keserasian dan keselarasan dengan Lingkungan.
\end{abstract}

Kata Kunci : Masterplan, Desa Wisata, Watulimo

\section{PENDAHULUAN}

Pariwisata merupakan salah satu industri yang berkembang pesat di Indonesia dan terbukti menyumbangkan pendapatan yang besar. Kepariwisataan akan terus berkembang selaras dengan perkembangan industrialisasi dan perubahan gaya hidup yang menyebabkan orang-orang semakin memiliki kemampuan untuk berwisata dan memiliki waktu yang lebih banyak untuk melakukan perjalanan, khususnya ke Indonesia. Melihat prospek kepariwisataan inilah, pemerintah Indonesia berusaha mengembangkan kepariwisataan secara lebih intensif, yakni dengan mempersiapkan dan memperbaiki kualitas objek dan atraksi yang ada dengan tetap menggali potensi wisata yang dimiliki, melakukan perencanaan, dan pengelolaan pembangunan kepariwisataan yang lebih baik. Dengan demikian, diharapkan Indonesia mampu merebut pasar wisatawan dan bersaing dengan berbagai destinasi wisata yang ada di dunia.

Kabupaten Trenggalek merupakan salah satu kabupaten di Provinsi Jawa Timur yang memiliki daya tarik wisata bagi wisatawan yang datang mengunjunginya. Pengembangan pariwisata Kabupaten Trenggalek diarahkan pada pengembangan wisata alam dan budaya, pemasaran daya tarik wisata, pembinaan dan pengembangan nilai-nilai budaya, pembinaan kesenian, peninggalan sejarah yang bertujuan untuk mengembangkan daya tarik wisata potensial sebagai daya tarik utama bagi wisatawan, yang menjadikan pariwisata sebagai sarana peningkatan pendapatan masyarakat, dan daerah, serta media bagi penciptaan lapangan dan kesempatan kerja. Dalam rangka pelaksanaan Pengabdian Masyarakat Pengembangan Desa Wisata Desa Watulimo Kec. Watulimo Kab. Trenggalek, telah dilakukan serangkaian kegiatan yang dimulai dengan Survei Pendahuluan, Pengumpulan Data Lapangan, Analisa Data dan pembuatan perencanaan wisata. Dalam kegiatan perencanaan ini akan dilakuan dengan proses kordinasi berkelanjutan sehingga segala masukan dan informasi bisa berguna untuk kelayakan suatu perencanaan teknis laporan pengabdian masyarakat dengan hasil yang diharapkan oleh semua pihak.

\section{LANDASAN TEORI}

Tinjauan Umum

Wisata alam adalah bentuk kegiatan rekreasi dan pariwisata yang memanfaatkan potensi sumberdaya alam, baik dalam keadaan alami maupun setelah ada usaha budidaya, sehingga memungkinkan wisatawan memperoleh kesegaran jasmaniah dan rohaniah, men-dapatkan pengetahuan dan pengalaman serta menumbuhkan inspirasi dan cinta terhadap alam (Anonymous, 1982 dalam Saragih, 1993) Kebijakan Pengembangan Obyek dan Daya Tarik Wisata antara lain adalah sebagai berikut:

1 Pengembangan obyek dan daya tarik wisata menyangkut aspek perencanaa, pemanfaatan dan pengendalian yang satu sama lainnya merupakan satu kesatuan yang terintegrasi, oleh karenanya pembangunan obyek dan daya tarik wisata harus didasarkan pada sistem perencanaan. 
Pengembangan Desa Wisata Kepung Budaya Desa Watulimo, Kecamatan Watulimo, Kabupaten Trenggalek Vega Aditama, Budi Fathony, Lalu Mulyadi

2 Pengembangan obyek dan daya tarik wisata dilakukan berdasarkan pendekatan pembangunan Satuan Kawasan Wisata dengan nuansa nilai agama, budaya, estetika dan moral yang dianut oleh masyarakat.

3 Pengembangan obyek dan daya tarik wisata dilakukan sesuai dengan mekanisme pasar dan meliputi wisata alam, wisata budaya, wisata minat khusus, wisata pantai dan wisata petualangan. Kabupaten Trenggalek merupakan Kabupaten yang memiliki banyak sumberdaya alam yang berpotensi untuk wisata alam. Visi Rencana Pembangunan Jangka Menengah Daerah Kabupaten Trenggalek, antara lain :

4 Meningkatkan kinerja birokrasi yang bersih, kompeten dan professional dalam memberikan pelayanan prima kepada masyarakat;

5 Meningkatkan pembangunan sektor pertanian serta memberikan perlindunganterhadap masyarakat untuk mewujudkan tata niaga yang adil dan menyejahterakan;

6 Mewujudkan peningkatan perluasan layanan infrastruktur, utamanya yang menunjang pengembangan pariwisata dan kawasan strategis;

7 Meningkatkan penciptaan lapangan kerja bagi SDM terdidik serta meningkatkan daya tarik investasi industri dengan memperhatikan kelestarian alam, ekonomi kerakyatan dan tatanan sosial masyarakat;

8 Meningkatkan sinergitas pembangunan dengan meningkatkan peran serta berbagai pihak; f) Meningkatkan pengembangan karakter masyarakat yang berkepribadian sebagai pilar pembangunan dengan berlandaskan iman dan takwa; dan

9 Meningkatkan keberpihakan pemerintah dalam mengentaskan masalah kemiskinan bagi masyarakat yang berpenghasilan rendah Maka dalam sangat jelas bahwa pengembangan desa watulimo bisa menjadi salah satu wujud nyata dalam melaksanakan visi Rencana Pembangunan Jangka Menengah Daerah Kabupaten Trenggalek, seperti digambarkan dalam alur berikut :

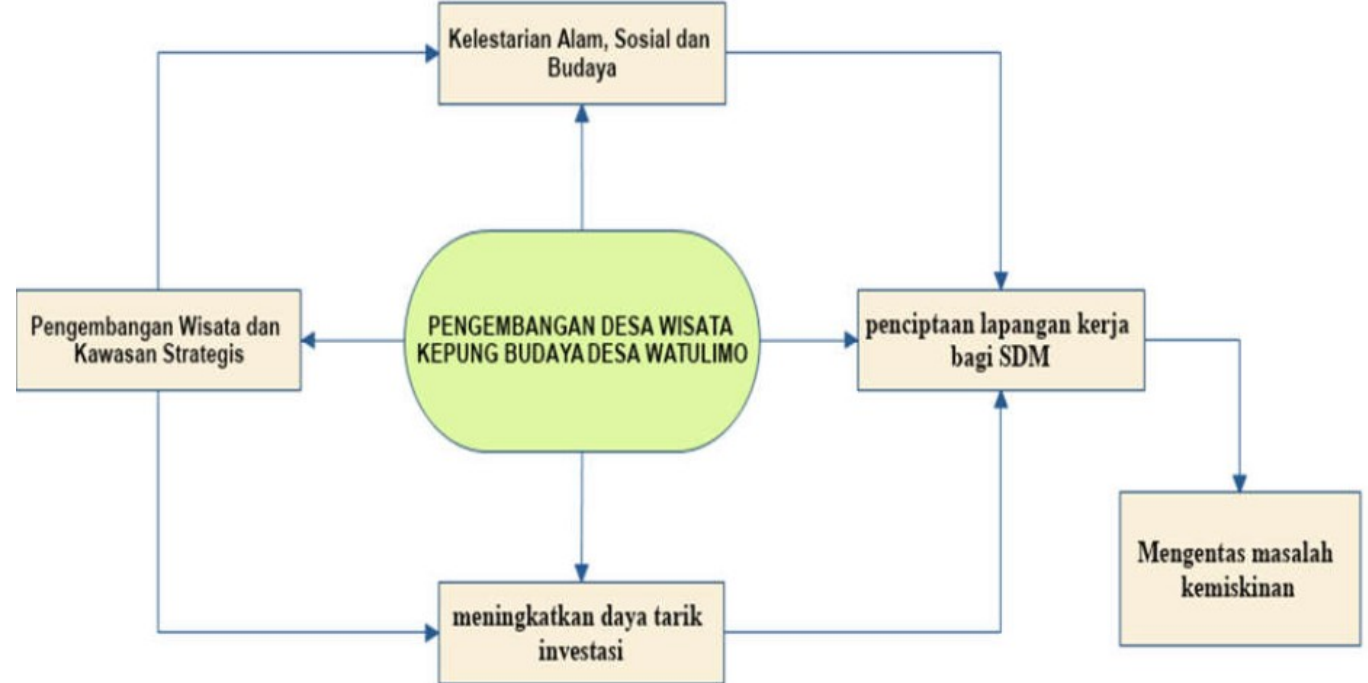

Gambar 1. Pengembangan Desa Wisata Kepung Budaya dalam RJPM

\section{Kondisi Site}

Desa watulimo merupakan salah satu dari 152 (seratus lima puluh dua) Desa yang ada diwilayah Kabupaten Trenggalek. Kondisi wilayah Desa Watulimo adalah pegunungan. Wilayah Desa Watulimo berada pada ketinggian 345 diatas permukaan air laut dengan Luas Desa 1100,7 Ha. Dengan batas wilayah sebagai berikut :

Tabel 1. Batas Wilayah Desa Watulimo

\begin{tabular}{|l|l|}
\hline - Sebelah Utara & : Desa Watuagung, Kecamatan Watulimo \\
\hline - Sebelah Selatan & : Desa Gemaharjo, Kecamatan Watulimo \\
\hline - Sebelah Timur & : Desa Sedayugunung, Kecamatan Besuki \\
\hline - Sebelah Barat & : Desa Pakel, Kecamatan Watulimo \\
\hline
\end{tabular}

Dari pengamatan di lokasi site terdapat beberapa bangunan eksisting yaitu:

1. Persawahan

2. DAM

3. Rumah Budaya

4. Masjid 
Pengembangan Desa Wisata Kepung Budaya Desa Watulimo, Kecamatan Watulimo, Kabupaten Trenggalek Vega Aditama, Budi Fathony, Lalu Mulyadi

\section{Perumahan}

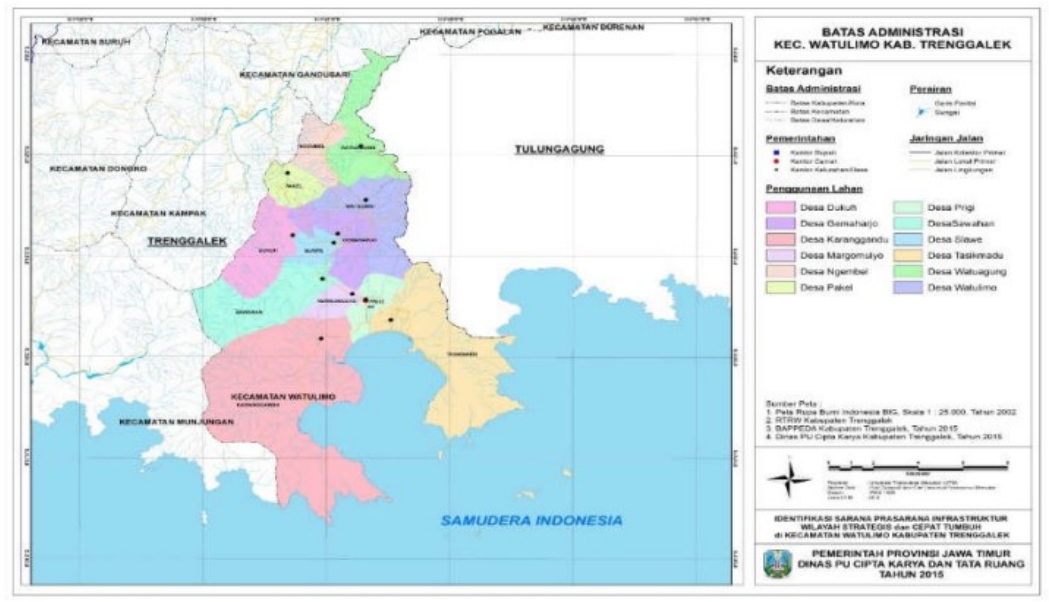

Gambar 2. Peta Batas Administrasi Kecamatan Watulimo

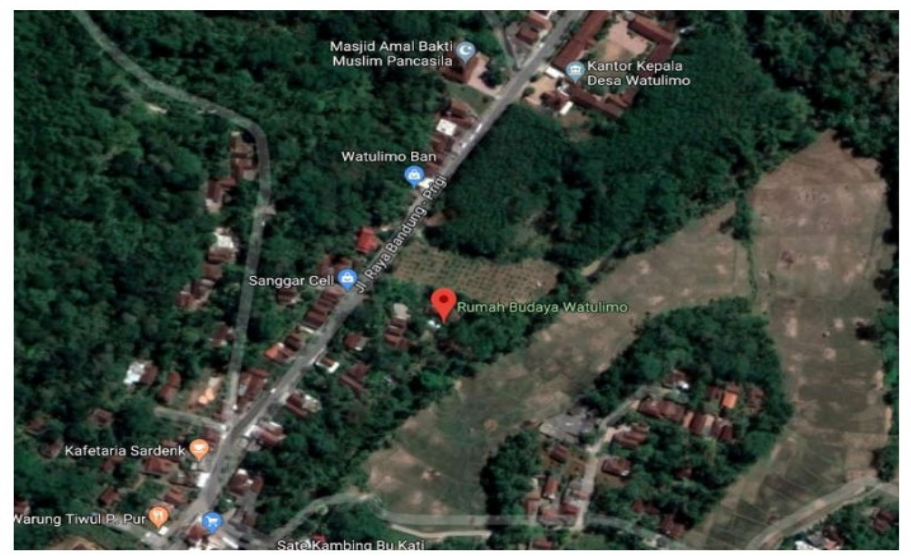

Gambar 3. Site Plan Desa Wisata Budaya Watulimo

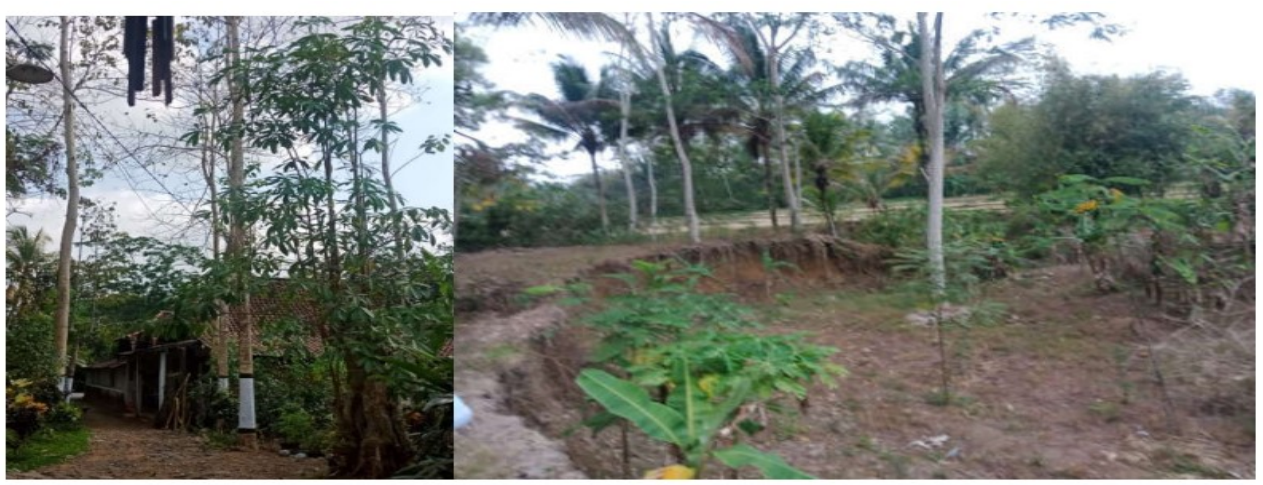

Gambar 4. Existing Perencanaan 


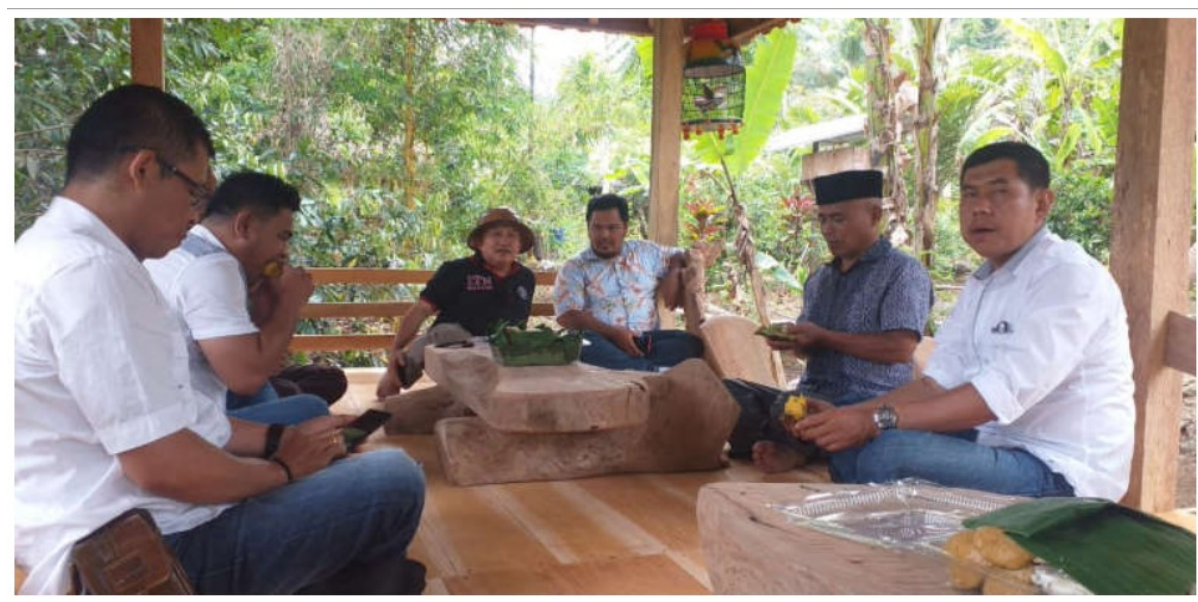

Gambar 5. Pengumpulan data melalui audiensi kepada warga lokal.

\section{KARAKTERISTIK PENGGUNAAN LAHAN}

Watulimo, Margomulyo, Sawahan, Dukuh, Slawe, Gemaharjo, Pakel, Ngembel dan Watuagung. Berdasarkan topografinya, desa yang berada di Kecamatan Watulimo merupakan perbukitan dan pantai. Kecamatan Watulimo memiliki luas 15.609, $57 \mathrm{Ha}$. Terdiri dari 7.854,11 Ha lahan Hutan, 1.395,24 Ha lahan Kebun, 1.500,24 Lahan Permukiman, 658,76 Ha Lahan Sawah Irigasi, 39,06 Ha Lahan Sawah Tadah Hujan, 3.120,94 Ha lahan Semak Belukar, 86,11 Ha Lahan Tanah Berbatu, dan 955,11 Ha lahan Tegalan.

\section{SEKTOR PARIWISATA}

Obyek wisata alam pada Kecamatan Watulimo berupa pantai, gua, dan pegunungan. Ada 2 (dua) jenis kawasan wisata andalan yang ada di Kecamatan Watulimo yaitu kawasan wisata alam dan wisata budaya. Kawasan wisata alam banyak menonjolkan keindahan alam sedangkan kawasan wisata budaya menyajikan unsur budaya dan sejarah. Kawasan wisata alam di Kecamatan Watulimo berupa pantai Prigi, pantai Karanggongso serta pantai Damas. Sedangkan wisata budaya seperti Upacara labuh laut di Kecamatan Watulimo. Beberapa lokasi wisata yang telah menjadi trade mark atau tetenger bagi Kabupaten Trenggalek saat ini, khususnya yang berada di Kecamatan Watulimo adalah Pantai Prigi di Desa Tasikmadu, Pantai Pasir putih/ karanggongso di Desa Tasikmadu, Pantai Damas di desa Karanggandu, Gua Lawa di Desa Watuagung, dan Panjat tebing Gunung Sepikul di desa Watuagung.

\section{POTENSI WILAYAH}

Beberapa potensi yang dimiliki oleh Kecamatan Watulimo, yaitu antara lain:

1 Memiliki lokasi yang cukup strategis, adanya keterkaitan sistem regional jaringan transportasi dan fungsi kawasan terhadap wilayah perkotaan yang lebih tinggi yaitu keberadaan Jalan Lintas Selatan (JLS) Jawa Timur yaitu Pacitan-Trenggalek-Tulungagung.

2 Terdapat jalan penghubung antar wilayah (Watulimo-Munjungan-Panggul).

3 Memiliki keberadaan objek wisata berupa; Pantai Prigi di Desa Tasikmadu, Pantai Pasir Putih di Desa Tasikmadu, Pantai Damas di Desa Karanggandu, Gua Lawa di Desa Watuagung, dan Panjat Tebing Gunung Sepikul di Desa Karanganyar. Selain itu juga terdapat potensi wisata budaya berupa atraksi wisata Upacara Labuh Laut (budaya masyarakat pesisir).

4 Masih luasnya lahan pertanian, selain untuk kegiatan produksi pertanian dapat difungsikan sebagai daya tarik wisata dalam bentuk kegiatan edukasi;

5 Terdapat beberapa fasilitas pendukung yang dapat menunjang kegiatan ekonomi di Kecamatan Watulimo, salah satunya Pasar dan Pelabuhan Perikanan.

6 Sektor unggulan lainnya adalah pariwisata dimana salah satu wilayah terdapat objek dan atraksi wisata. Pantai prigi di Desa Tasikmadu, Pantai Pasir putih karanggongso di Desa Tasikmadu, Pantai Damas di desa Karanggandu, Gua Lawa di Desa Watuagung, Panjat tebing Gunung Sepikul di Desa Watuagung. Atraksi Wisata yang merupakan bagian dari wisata budaya yang terdapat di Watulimo yaitu Upacara Labuh Laut.

Peta Koordinasi Pengabdian Masyarakat

Dalam memperoleh data yang dibutuhkan dan gagasan dari masyarakat dan pemerintah Kab. Trenggalek maka diperlukan kordinasi - kordinasi yang digambarkan dengan gambar berikut: 


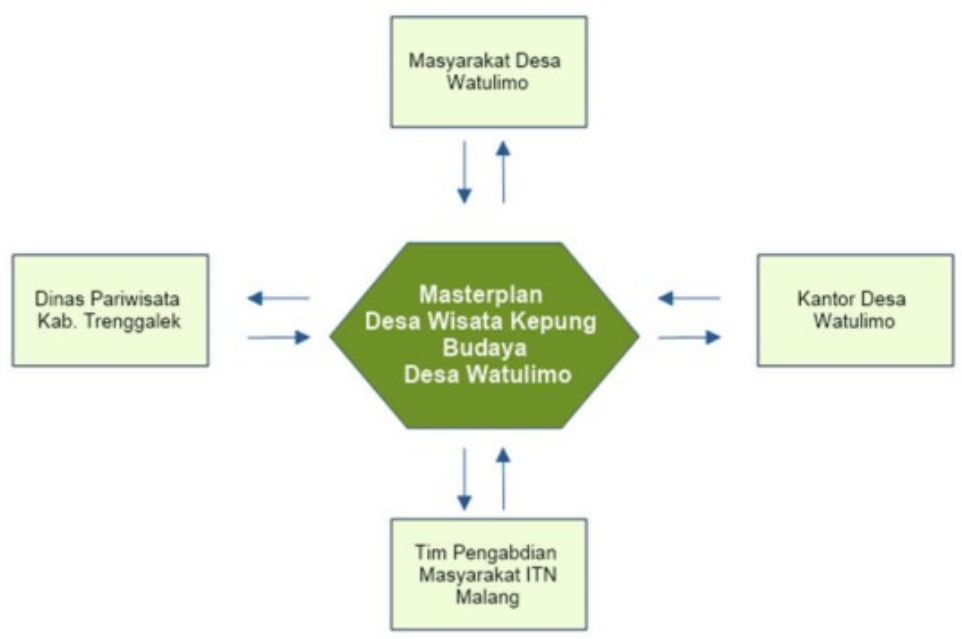

Gambar 5. Peta Koordinasi Pengabdian Masyarakat

\section{KRITERIA DESAIN DAN HASIL DESAIN}

\section{Kriteria Desain}

Perancangan perencanaan pengembangan Desa wisata Kepung budaya desa Watulimo kecamatan Batulima Kabupaten Trenggalek tahun 2019 ini difungsikan sebagai acuan dalam pengembangan design wisata sehingga dapat memudahkan dalam menyusun rencana pengembangan jangka pendek dan rencana pengembangan jangka panjang. Masterplan ini diharapkan dapat memenuhi kebutuhan ruang dan mewadahi kegiatan dan kebutuhan sirkulasi antara kegiatan. Untuk mau jutkan bangunan dan hubungan antar bangunan yang dapat berfungsi sebagai mestinya maka perencanaan pengembangan Desa wisata Kepung budaya desa suatu lima kecamatan Watu lima kabupaten Trenggalek tahun 2019 harus mampu memfasilitasi kegiatan kegiatan padadesa bisa tak budaya ya Watulimo yang meliputi budaya seni, Arya wisata area terbuka hijau dan Pelestarian alam dengan pendekatan konsep arsitektur tradisional danberwawasan lingkungan. Pendekatan konsep arsitektur tradisional dan arsitektur berwawasan lingkungan yang akan diperhatikan pada perencanaan ini adalah:

1. Arsitektur tradisional mewujudkan budaya masyarakat berdasarkan pada nilai kepercayaan yang dianut pada simbol simbol kosmologis Yang diterapkan dalam elemen bentuk arsitekturna

2. Konsep penekanan design Ekologi arsitektur didasari dengan maraknya isu global war ming. Dihadapkan dengan konsep rancangan yang berdasar pada keseimbangan alam ini, dapat mengurangi pemanasan global sehingga suhu bumi tetap terjaga

3. Pendekatan design yang ekologis. Pendekatan design arsitektur yang menggabungkan alam dengan teknologi menggunakan alam sebagai basis design, strategi konservasi, perbaikan lingkungan, dan bisa diterapkan pada semua tingkatan dan skala untuk masih kan suatu bentuk bangunan, lanskap, permukiman dan kota yang Revolusioner dengan mewujudkan teknologi dalam perancangannya

4. Mewujudkan bangunan yang berwawasan lingkungan yang sering disebut dengan green Bullding. Hal ini erat kaitannya dengan konsep arsitektur hijau yang merupakan bagian dari arsitektur berkelanjutan

5. Pola perencanaan arsitektur suatu bangunan selalu memanfaatkan peredaran alam sebagai berikut:

a. Menciptakan kawasan Jawan diantara kawasan pembangunan

b. menggunakan bahan bangunan alamiah dan intensitas energi yang terkandung dalam bahan bangunan maupun yang digunakan pada saat pembangunan harus seminimal mungkin

c. Bangunan sebaiknya diarahkan menurut orientasi timur barat dengan bagian utara Selatan menerima cahaya alam tanpa kesilauan

d. Dinding harus sesuai dengan kebutuhan iklim ruang dalamnya

e. Menghindari kelembapan tanah naik ke dalam konstruksi bangunan dan memajukan sistem konstruksi bangunan kering

\section{Hasil Desain Persyaratan Teknis Struktur}

Sistem struktur bangunan dibagi menjadi tiga bagian yaitu:

1. Pondasi : Fondasi adalah struktur bangunan yang berfungsi menyalurkan beban yang diterima oleh penggunaan ketanah, jenis fondasi yang digunakan adalah udah sedang call dan fondasi menengah 
sesuai dengan kebutuhan bangunan yaitu udah sih batu kali untuk bangunan satu lantai dan udah sih Tapak setempat untuk bangunan dua lantai. Pemilihan ini didasarkan atas tinjauan terhadap pondasi tapak tapak yang rawan gempa, penyaluran beban maksimal, beban yang diterima, serta kemudahan pengadaan barang dan pelaksanaan

2. Struktur badan bangunan : Struktur utama yang digunakan bervariasi sesuai sunnah perencanaan yaitu menggunakan bahan alam wisata dan untuk bangunan gedung menggunakan kolom dan struktur Beton bertulang dengan dimensi yang sesuai dengan persyaratan dan peraturan yang berlaku. 3. Struktur Atap : Struktur atap yang digunakan adalah struktur rangka ruang dengan material kayu berkualitas tinggi untuk bangunan bisa Hatta dan untuk bangunan gedung struktur rangka ruang dengan material aluminium berkualitas tinggi.

\section{Arsitektur}

Arsitektur bangunan yang perlu diperhatikan meliputi bangunan tata ruang dalam, keseimbangan, keserasian dan keselarasan dengan Lingkungan. Fasade bangunan mengaju pada ke estetika bentuk, karakteristik arsitektur dan lingkungan yang ada disekitarnya. Fasade bangunan merupakan perpaduan arsitektur tradisional dan arsitektur berwawasan lingkungan, sehingga tercipta keserasian yang berkesinambungan antara malam dan baru. Penggunaan material yang pengaruhi setiap bangunan mengikuti konsep arsng diterapkan dengan mempertimbangkan lingkungan, Kemudahan pelaksanaan tata ruang dalam harus di perhatikan fungsi ruangan yang efektif dan efisien. Tata ruang dalam juga memperhatikan kenyamanan, keselamatan dan kemudahan tata ruang dalam.

\section{Utilitas}

1. Sistem instalasi listrik, Sistem instalasi mempergunakan panel utama yang menggunakan sumber tenaga PLN dan Genset

2. Sistem penghawaan, Sistem penghargaan terbagi atas penghargaan alami untuk pariwisata dan penghargaan dua tahun untuk bangunan pengawet alami dengan manfaatkan dugaan dan sistem ventilation. Sistem buatan menggunakan AC Split. Sis tem Asih split pengaturan kondisi ruangan hanya untuk satu ruangan. Masih jenis ini dipergunakan untuk ruang yang kegiatannya tidak terus menerus.

3. Sistem Pembuangan sampah, sistem Pembuangan sampah setiap spot akan diberikan sampah atau tempat sampah pada setiap ruangan dan akan ditampung pada penampungan sementara kemudian diangkut ke pembuangan akhir

4. Sistem Pembuangan Air Kotor, Sistem Pembuangan air kotor dibagi menjadi dua yaitu jaringan air kotor chair dan padat. Jaringan air kotor chair akan disalurkan ke sumur resapan, Drainase, riol kota. jaringan air kotor padat akan disalurkan ke septictank

5. Sistem distribusi air bersih, Sistem distribusi air bersih menggunakan sumber alam yaitu sumber dan sumber air bersih dari PDAM

\subsubsection{Gambar Desain}

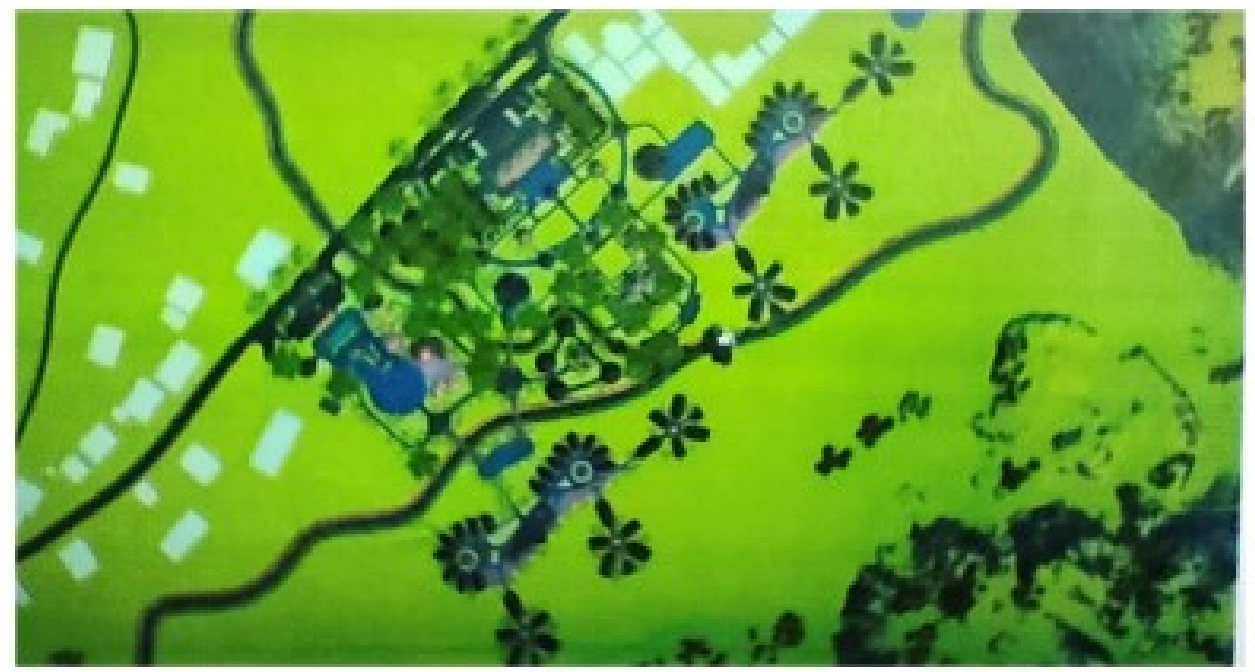

Gambar 6. Site Plan 
Pengembangan Desa Wisata Kepung Budaya Desa Watulimo, Kecamatan Watulimo, Kabupaten Trenggalek Vega Aditama , Budi Fathony, Lalu Mulyadi

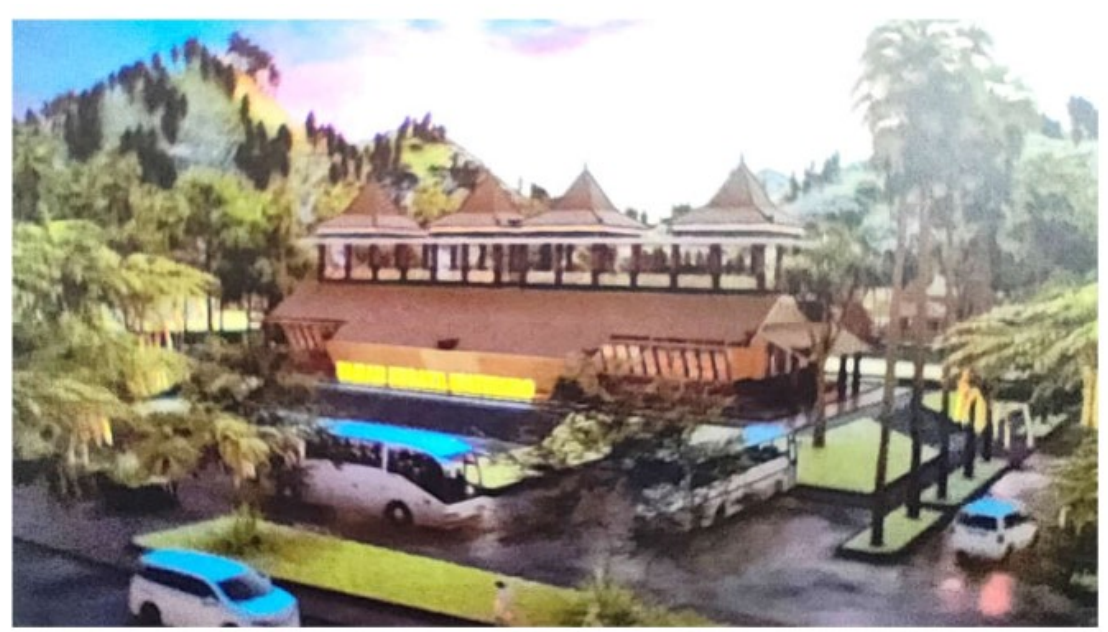

Gambar 7. Area Parkir dan Gedung Serbaguna

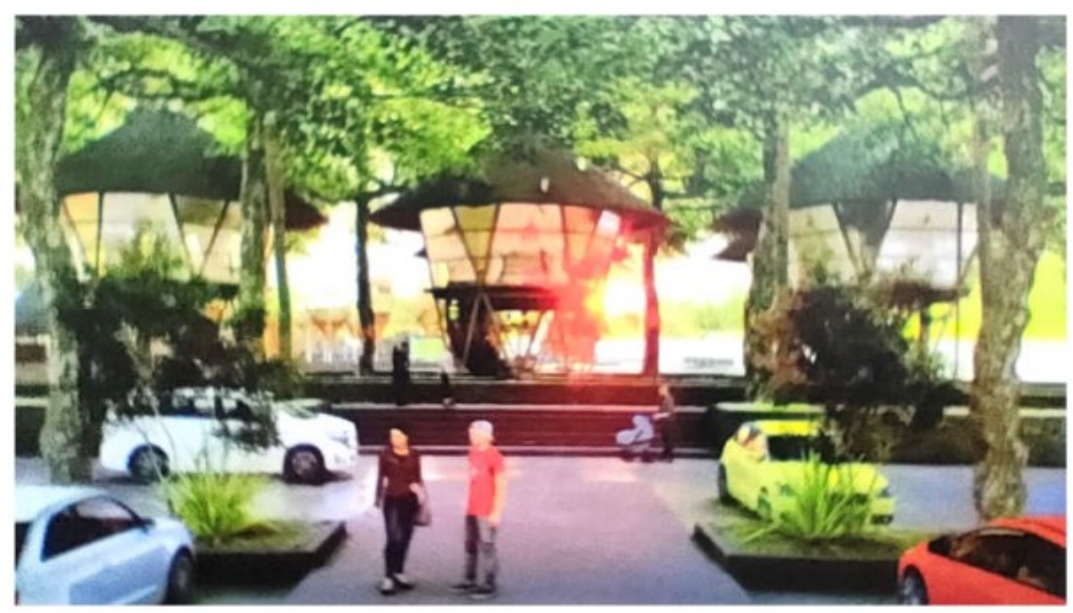

Gambar 8. Area Parkir dan Cottage

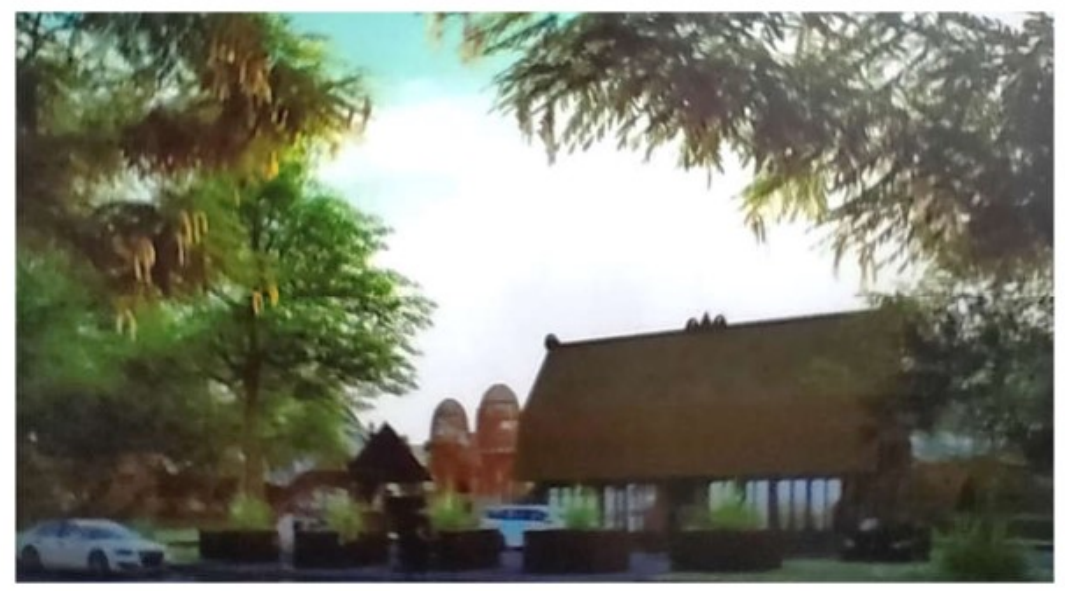

Gambar 9. Rumah Pengasapan 
Pengembangan Desa Wisata Kepung Budaya Desa Watulimo, Kecamatan Watulimo, Kabupaten Trenggalek Vega Aditama , Budi Fathony, Lalu Mulyadi

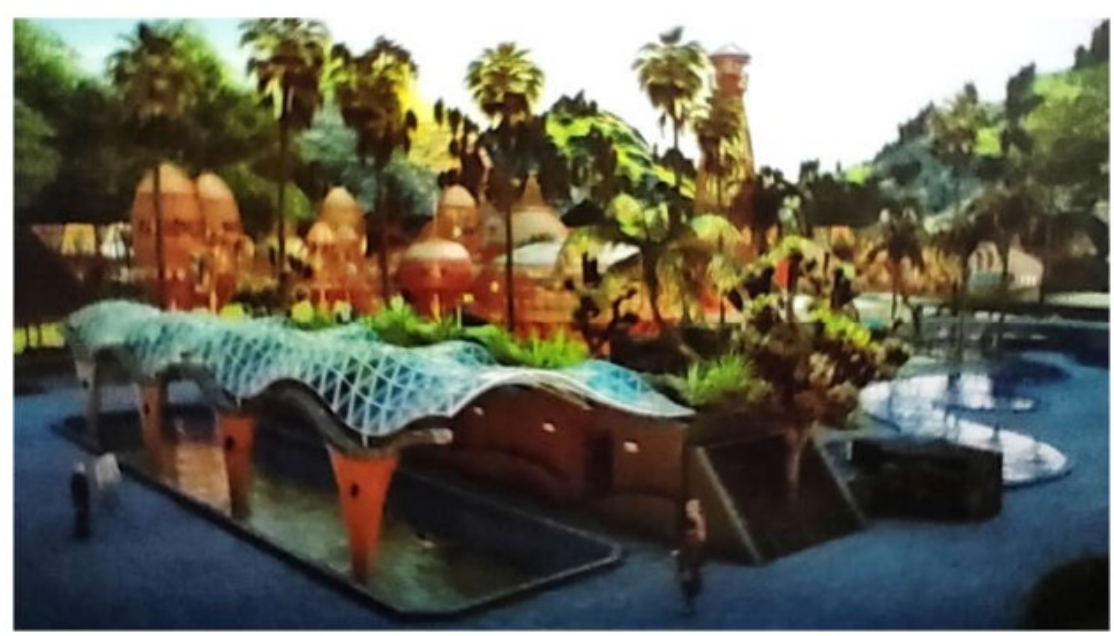

Gambar 10. Taman Wisata Air

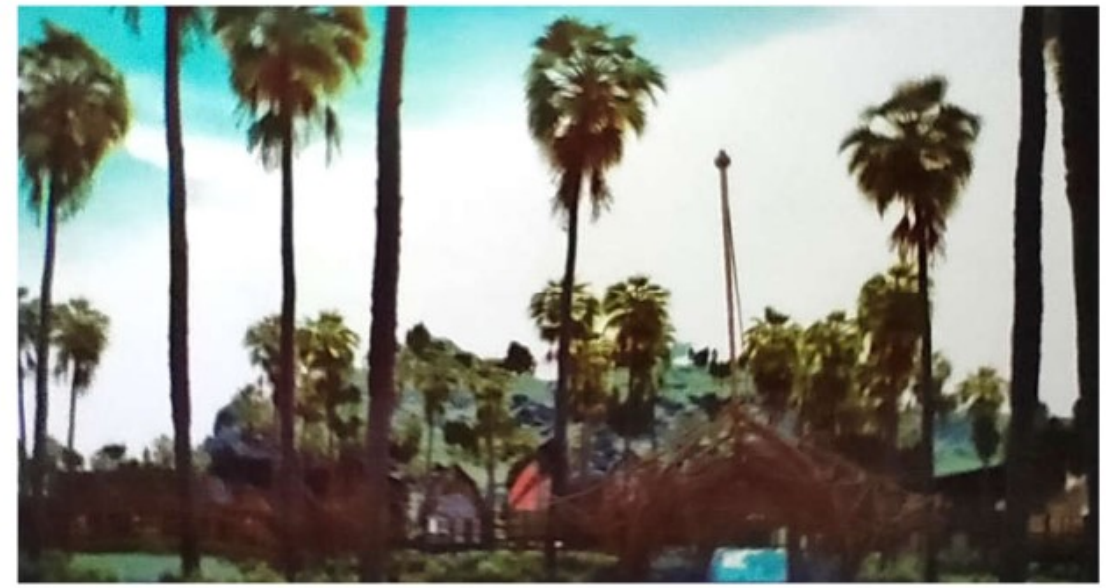

Gambar 11. Jembatan

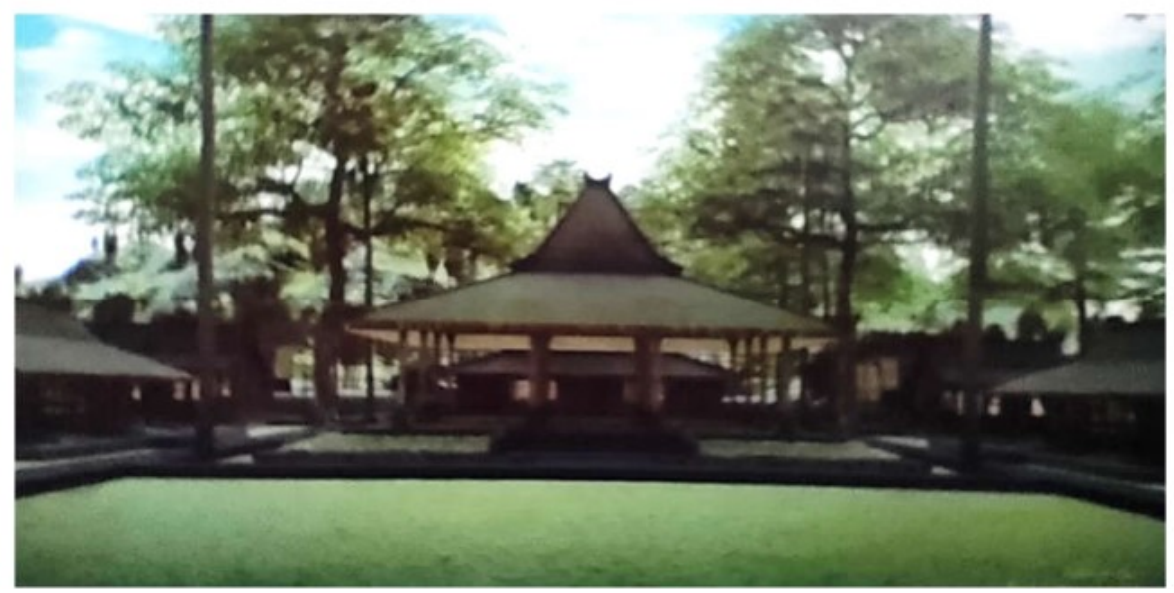

Gambar 12. Area Rumah Budaya 
Pengembangan Desa Wisata Kepung Budaya Desa Watulimo, Kecamatan Watulimo, Kabupaten Trenggalek Vega Aditama, Budi Fathony, Lalu Mulyadi

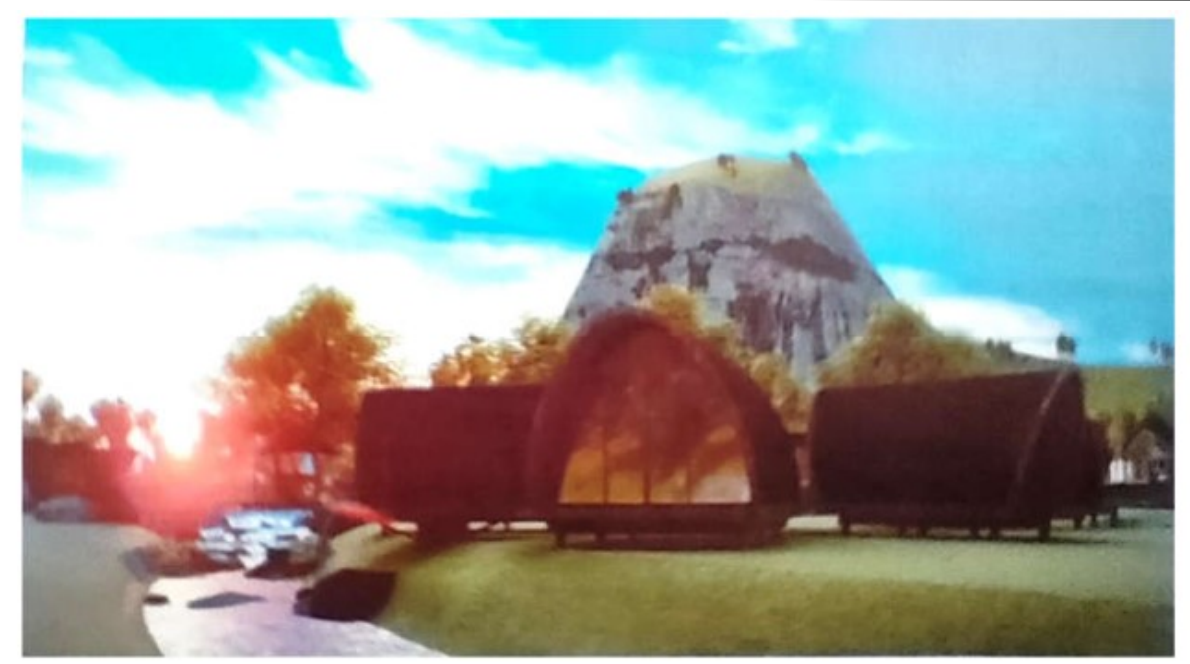

Gambar 13. Rest Area dan Rumah DAM

\section{Kesimpulan}

Dengan adanya pengabdian masyarakat ini diharapkan visi dan misi pengembangan Desa wisata Watulimo dapat di implementasikan dengan efektif dan efisien sehingga bermanfaat bagi masyarakat. Masterplan Desa Wisata Kepung Budaya dibuat dengan memperhatikan bangunan tata ruang dalam, keseimbangan, keserasian dan keselarasan dengan Lingkungan.

\section{Daftar Pustaka}

[1] Panggabean,Hana.Et.al.2014.Kearifan Lokal Keunggulan Global, Elex Media Komputindo,Jakarta

[2] RJPMD Kabupaten Trenggalek 2015-2019

[3] BPS Kabupaten Trenggalek. 2019. Trenggalek dalam angka

[4] BPS Kabupaten Trenggalek. 2019. Kecamatan Watulimo dalam angka

[5] Peraturan Pemerintah No.43 Tentang Pemberdayaan Masyarakat Desa

[6] Damanik,Janianton,Et.all.2015.Membangun Pariwisata Dari Bawah,Gajah Mada

University Press, Yogyakarta 